the study of trees much more intelligible and interesting when the meaning of structure and form is clearly and simply described to the student, as in the present work.

After this excellently written and beautifully illustrated introduction, the author takes up the gymnosperms. He does not attempt to deal with every known species, but certainly there are few which are likely to be met with in various pinetums, parks, and forests in this country which have not been dealt with. The life-history of each is clearly and well described and illustrated by photographs. As Prof. Groom states in his preface, "Particular trees have been selected for more detailed discussion, so as to serve as types by which to demonstrate certain structural features or general phenomena observable in treelife." The study of the conifers appeals to a vast number of people, and a distinct gap in the existing literature has been filled by this work. No doubt other books give descriptions of the different species, but these are too condensed and technical to be of any use to the general reader. The broad-leaved trees are similarly dealt with in an interesting and masterly manner. Analytical tables and diagnosis of families have been added. These, together with the numerous illustrations and the special mention of distinctive features which is prefixed to the account of every tree described, will certainly ensure facility and accuracy in identifying the different knds of trees with which the reader is likely to come in contact.

The author is to be congratulated upon the production of a work which should certainly be in the possession of all those interested directly or indirectly in trees and their growth.

A. W. B.

\section{DR. JAMES BELL, C.B., F.R.S.} $W_{\text {March }}^{\mathrm{E}}$ regret to have to announce the death, on James Bell, formerly principal of the Somerset House laboratory. Dr. Bell was a native of County Armagh, and entering the Inland Revenue Service became, when a comparatively young man, an assistant in the chemical department of Somerset House, then under the charge of Mr. George Phillips. This department, the forerunner of the present Government Laboratory, was the outcome of the Tobacco Act of $\mathrm{I} 84_{2}$, and was created with the object of supplementing the provisions of that Act in suppressing the adulteration of tobacco. For his chemical education Dr. Bell was mainly indebted to the late Prof. Williamson. Indeed, in the early days of the Somerset House laboratory a close association existed between it and University College, and a number of the first assistants were trained in theoretical and practical chemistry in the Gower Street laboratories, and some of them, like Duffy, Kay and Railton, were encouraged by Dr. Williarason, then in the full vigour of his scientific activity, to try their prentice hands at original investigation. In the first years of its existence the laboratory, the staff of which consisted solely of Mr. Phillips himself, was almost exclusively engaged on the objects for which it was founded, but as its utility became more and more apparent its operations were gradually extended, and eventually embraced the examination of practically every excisable article. The laboratory at this period was also largely concerned with inquiries as to the brewing values of various materials, and on the methods of determining original gravities, and on the denaturing of spirits of wine so as to permit its use for manufacturing purposes without danger to the revenue-all of which work found its application in subsequent Acts of Parliament.

On the death of Mr. Kay, Mr. Bell became deputy principal, and he continued in that office until the retirement of Mr. Phillips in $1_{74}$, when he succeeded to the principalship, holding that position until his resignation in 1894 . During the fifty years of its existence the operations of the laboratory had greatly extended, and it had contracted associations with practically every Government department which had need of chemical advice and assistance, in addition to the large extension of its work connected with Revenue matters. Much of this development took place during Dr. Bell's principalship. But to the public at large Dr. Bell's tenure of the office was mainly signalised by the association of the Somerset House laboratory with what is in reality one of the least important of its many duties, viz. the Food and Drugs Acts. This popular misapprehension of the proper functions of the laboratory is no doubt due to occasional newspaper references to the fact that a disputed case of analysis of some food-stuff, drink or drug has been referred by magistrates to the Commissioners of Inland Revenue for the opinion of their chemical advisers. As a matter of history, this connection of the Somerset House laboratory with the Food and Drugs Acts occurred at the very time that Dr. Bell succeeded to the principalship, as a result of a report of a Select Committee of the House of Commons on the working of the Act of 1872 , and this circumstance caused the laboratory to be known to the public at large to a much greater extent than formerly.

The new responsibility thus thrown on Dr. Bell involved a very considerable increase of work on the department, not so much in actual analysis of referred samples as in investigations into the methods of food analysis in general and in the establishment of standards of quality. Thirty years ago the methods of food analysis were, for the most part, in a very unsatisfactory condition. The great teachers of chemical analysis, Berzelius, Rose, Wöhler, Thomson, Bunsen, Fresenius, and the men trained in their schools, were mainly concerned in the discovery and elaboration of the methods of mineral analysis, and very little attention had been paid to processes for the systematic examination of food with a view to the determination of its quality or to the detection of adulteration. The first Food and Drugs Act was largely ineffective owing to this circumstance. When the office of a public analyst was first created, practically each analyst had to devise his own methods, and at the outset no uniformity or agreement was possible. The condition of things to which this gave rise, with the consequent frequent instances of injustice, was indeed the cause of the appointment of the Select Committee above referred to.

As regards methods of analysis, Dr. Bell, as the referee eventually appointed under the Act of 1875 , was in no better position than other analysts who held office under the Act, and he at once turned all the force and ability of his laboratory to the elaboram tion of the methods for the examination of such articles of food and drink as experience showed most frequently came within the purview of the Act. In this work he was assisted by some of the most competent analysts the laboratory ever possessed, notably Mr. George Lewin, the late Mr. Harkness, the late Mr. John Holmes, and Mr. Cameron, each of whom did yeoman service in getting together the material embodied in the work by which Dr. Bell is best known, viz. his "Chemistry of Foods." It was mainly in recognition of the service thus rendered to the community that Dr. Bell was elected into

NO. 2006, vOL. 77$]$ 
the Royal Society in 3884 , and was made, two years later, a graduate of the Royal University of Dublin. His official position further led to his selection as president of the Institute of Chemistry in I888. He was one of the original members of the Institute, and took much interest in its operations. He was made a Companion of the Bath in 1889 .

Dr. Bell enjoyed the respect and esteem of many successive Boards of Inland Revenue, who found in him a shrewd and astute adviser of ripened judgment and large experience, eminently cautious and sound. His bonhomie and geniality, his strong common sense and tactful sympathy, his fairmindedness and obvious impartiality rendered him an admirable agent in the conduct of the occasionaliy complicated and difficult adjustments of the apparencly conflicting interests of the "Trade" and the Revenue, which the head of the laboratory is now and again called upon to determine. He was loyally served by his staff, who entertained warm feelings of regard and affection for him. Many of them testified to their appreciation of his many good qualities by their presence at his funeral on Saturday last at Ewell.

T. E. T.

\section{NOTES}

THE sixteenth James Forrest lecture of the Institution of Civil Engineers will be delivered at the institution on Monday, April 27, by Prof. Henry Louis, who has selected for his subject "Unsolved Problems in Metal Mining."

TuE Geological Society of London is taking a poll of all the fellows resident in the United Kingdom to ascertain whether a majority is in favour of admitting women to the society, and, if so, whether as fellows or as associates.

DR. W. N. Sraw, F.R.S., and Dr. T. H. Warren, Vice-Chancellor of the University of Oxford, have been elected members of the Athenæum Club under the provisions of the rule of the club which empowers the annual election by the committee of three persons " of distinguished eminence in science, literature, the arts, or for public services."

Dr. Henri Deslandres, who since 1897 has been assistant director of the observatory at Meudon, has been appointed director to succeed the late Dr. Janssen.

Dr. J. N. Langley, F.R.S., professor of physiology in the University of Cambridge, has been elected a foreign member of the Royal Danish Scientific Society.

THE third International Congress of Philosophy will be held at Heidelberg from August $3 \mathrm{I}$ to September 5. Prof. Windclberg is to be president, and Dr. Elsenhaus Plock, of Heidelberg, is acting as secretary.

THE annual dinner of the Institution of Mining and Metallurgy will be held at the Hotel Cecil on Friday, May 8. The president, Mr. A. James, will preside, and many distinguished guests have already accepted invitations to be present.

WE learn from the British Medical Journal that the Town Council of West Han has passed a resolution authorising the placing of a bronze tablet on the house in Upton Lane, Forest Gate, now St. Peter's Vicarage, where Lord Lister was born.

THE sixth International Congress of Psychology will be hold at Geneva from August $3 \mathrm{I}$ to September 4, 1909. Prof, E. Claparède, professor of physiological psychology NO. 2006, VOL. 77 ] in the University of Geneva, is the general secretary of the congress, and may be addressed at Champel, in, Geneva.

A NEW Polar expedition is being equipped, under the auspices of the Russian Ministry of Marine, with the object of discovering a north-east passage between the Atlantic and Pacific Oceans, and thereby accelerating naval communication between Western and Far Eastern Russia.

A correspondint sends us a page from "Wind und Wetter," by Prof. E. Lommel (Munich : R. Oldenbourg, 1873), containing a description of the dark cloud which covered Europe and a part of Asia in 1873 (see Nature, March 5, p. 4'7, and March 26, p. 493).

THE body of Emanuel Swedenborg, who died in $177^{2}$ and was buried in the Swedish Church, Prince's Square, Rateliff Highway, was removed on Tuesday from its place of sepulture and conveved to Dartmouth, where it was placed on board the Swedish cruiser Fylgia for conveyance to Siveden.

A General mecting of the American Philosophical Society will be held at Philadelphia on April 23-25. The preliminary programme, a copy of which has reached us, shows that thirty-six papers on important scientific subjects will be brought before the meeting by leading men of science in the United States.

THE Back bequest for roo $S$ has been awarded by the Royal Geographical Society to Lieutenant George Mulock, R.N., on account of the survey work which he did on the National Antarctic Expedition, and the map in six sheets which he prepared after the expedition returned.

A MESSAGE from Stockholn states that it is the intention of the Swedish Government to ask the Riksdag to make a grant for a scientific expedition to Spitsbergen in the coming summer for geological and geographical research. Prof. Gerard de Geer, the Rector of the University of Stockholm, will be the leader of the expedition.

IT is proposed to hold a conference of meteorologists representative of the United Kingdom and of the British colonies and dependencies in the course of the summer in Canada on the invitation of the Royal Society of Canada. The meeting was originally fixed for the last week in Mav. We are now informed by Mr. R. F. Stupart, director of he Canadian Meteorological Service, that it has been postponed, and is to be hold in Quebec in the last week of July, immediately after the celebration of the tercentenary of Champlain's landing.

Ax adult living specimen of Lepidosiren paradoxa-the South American lung-fish-reached the natural history department of Glasgow University some months ago, and has remained in a healthy condition. To this--the first living specimen which has ever reached the Old Worldthere have just been added cight others obtained by $\mathrm{Mr}_{\mathrm{r}}$. W. E. Agar on his recent expedition. It is hoped that in time it may be found possible to induce them to breed in captivity.

THE summer meeting of the American Association for the Advancement of Science will be held at Dartmouth College, Hanover, N.H., during the week beginning June 29. A committee, under the chairmanship of Prof. R. Fletcher, has been appointed to make the necessary arrangements. An invitation has been received from the president of the Blue Mountain Forest Association for members of the association to visit the Blue Mountain Forest, otherwise known as the Corbin Blue Mountain Park or Preserve, covering about 40,000 acres, where the celebrated herds of buffalo, deer, mountain goats, boars, \&c., may be seen. 